\title{
IMMUNOCYTOCHEMICAL DEMONSTRATION OF CALCITONIN IN THE DIDELPHIS ALBIVENTRIS THYROID
}

\author{
H. B. COUTINHO; G. KING*; T. I. ROBALINHO; V. B. COUTINHO \& T. J. CALADO \\ Centro de Pesquisas Aggeu Magalhàes/FIOCRUZ, Caixa Postal 7472, 50730 Recife, PE, Brasil \\ -Department of Pathology, University of Aberdeen, Scotland, UK
}

Differing from the studied Eutheria the Didel. phis virginiana thyroid presents cells. containing large cytoplasmic granules. They are located in the follicle wall beside follicular cells or forming cellular clusters among the follicles (R. R. Bensley, 1914, Anat. Rec., 8: 431-440). Similar cells were reported to exist in the thyroid of $D$. albiventris and D. marsupialis (G. Azzeli, 1964, Ann. En docr., 25: 8-13). After intravenous administration of calcium gluconate in adult $D$. albiventris a great depletion of cytoplasmic granules content was noticed suggesting the involvement of those cells in the synthesis of calcitonin $(\mathrm{H}$. B. Coutinho et al., 1969, Rev. Bras. Pesq. Méd. Biol., 2: 117-120).

In an attempt to confirm Coutinho et al. hypothesis a study was performed to verify by the use of immunocytochemical method the presence of calcitonin in the mentioned cells of the $D . a l$ biventris thyroid.

Thyroids obtained from five adult male opossums were fixed in Bouin's fluid and embedded in paraffin. $5 \mu \mathrm{m}$ sections were dewaxed in xylene and rinsed in alcohol. Endogenous peroxidase was blocked by fresh methanol $(90 \mathrm{ml}) / 30 \% 100$ vols $\mathrm{H}_{2} \mathrm{O}_{2}(3 \mathrm{ml})$ for $15 \mathrm{~min}$. After a running water rinse the sections were immersed in two changes of trisbuffered saline (TBS), 5 min each. The sections were incubated in normal swine serum (NSS) DAKO $X 901$, diluted $1 / 5$ in TBS for $15 \mathrm{~min}$. Without washing off NSS, rabbit polyclonal anti calcitonin antibody (DAKO A 576) diluted $1 / 50$ in TBS was applied on the sections overnight. The sections were rinsed in TBS $(3 \times 10 \mathrm{~min}$ each $)$. Secondary biotin labelled swine anti-rabbit immunoglobulin (DAKO E 353) 1/300 dilution in
TBS was applied for $30 \mathrm{~min}$. Sections were rinsed in TBS ( $3 \times 10 \mathrm{~min}$ each). sABC-HRP complex (DAKO K 377) prepaired a minimum of $30 \mathrm{~min}$ before use (strept Avidin $45 \mu \mathrm{l}$, Biotinylated Horseradish Peroxidase $45 \mu \mathrm{l}$, and $0.05 \mathrm{M}$ Tris $/ \mathrm{HCL}$ buffer $\mathrm{pH} 7.6(5 \mathrm{ml})$ was applied on the sections. The sections were rinsed in TBS $(3 \times 10 \mathrm{~min}$ each). Peroxidase demonstration was by the $\mathrm{H}_{2} \mathrm{O}_{2}-$ diaminobenzidine reaction (R. C. Graham \& M. J. Karnovsky, 1966, J. Histochem. Cytochem., 14: 291-302), resulting in a brown coloured, alcohol insoluble reaction product $(0.05 \mathrm{M}$ TRIS/ $\mathrm{HCl} \mathrm{pH}$ $7.6-100 \mathrm{ml}, 3,3$ diaminobenzidine tetrahydrochloride Sigma D-5673 - $30 \mathrm{mg}, \mathrm{H}_{2} \mathrm{O}_{2}-5$ drops). The reaction was allowed to continue for $10 \mathrm{~min}$ after which it was stopped by immersion of the slides in running water. The sections were counterstained in Harris' haematoxylin $(5 \mathrm{sec})$, and washed in running water, dehydrated in graded alcohols, cleared in xylene and mounted. For the polyclonal rabbit system the negative control was provided by the substitution of rabbit primary antibody with a normal rabbit immunoglobulin fraction (DAKO $\times$ 903) applied at a dilution of $1 / 500$ in TBS.

In the stained sections all granulous cells described in the opossum thyroid gave a positive reaction for calcitonin whilst the typical follicular cells were negative. No positive stain was noticed in control sections (Figs 1 and 2).

Notwithstanding the fact the $\mathrm{C}$ cells of the Metatheria $D$. albiventris thyroid differ morphologicaly from the Eutheria thyroid $\mathrm{C}$ cells, they are also related to the synthesis of calcitonin as Coutinho et al. have previously suggested. 

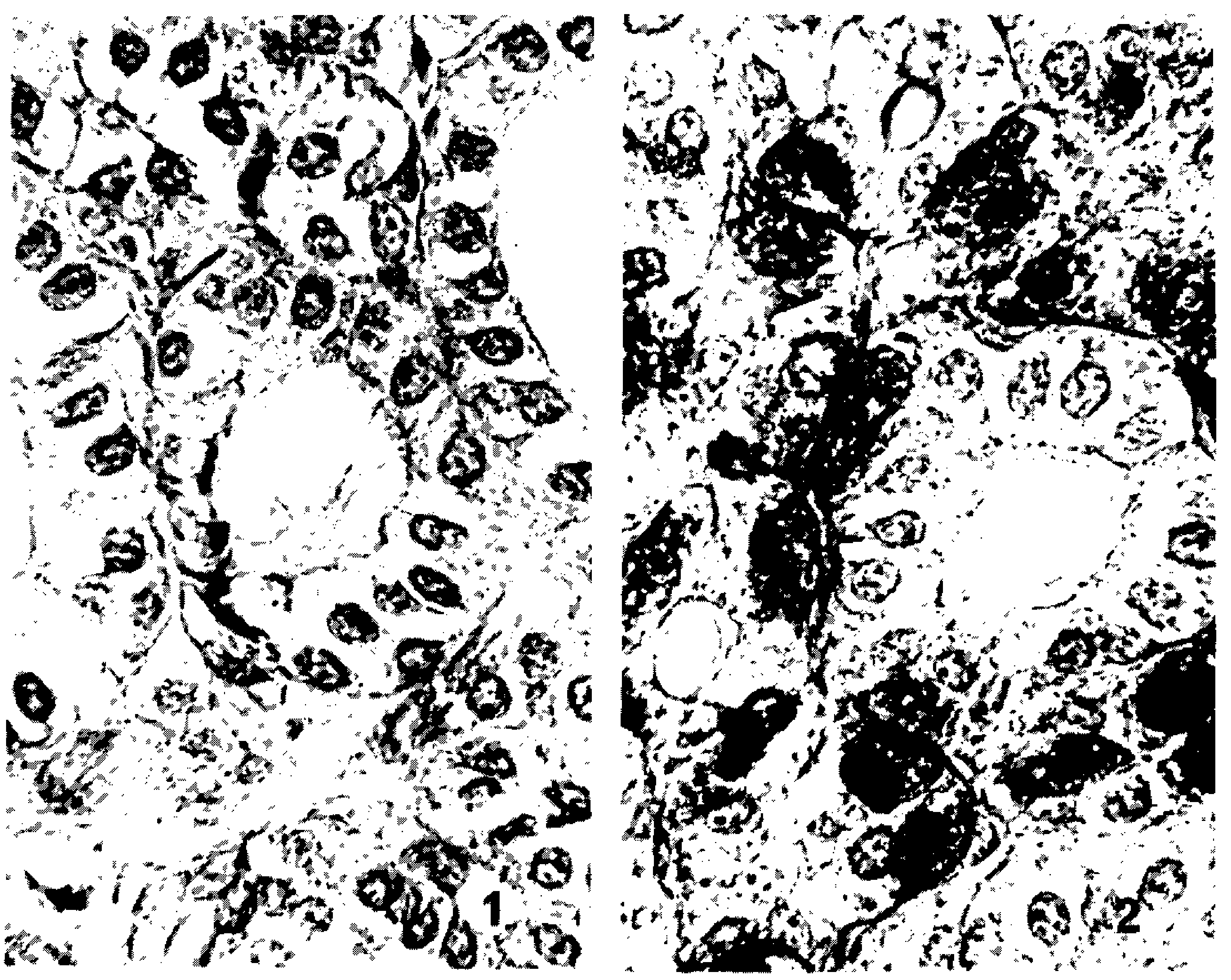

Fig. 1: control section incubated with normal rabbit immunoglobulin. The $C$ cells of the opossum thyroid are unstained. Counterstained by Harris' haematoxylin. X 800. Fig. 2: immunocytochemical demonstration of calcitonin in the cytoplasmic granules of the opossum C cells. Follicle cells are unstained. Counterstained by Harris' haematoxylin. X 800. 